\title{
ORGANIZATIONAL CITIZENSHIP BEHAVIOR (OCB) KARYAWAN DI UNIT REKAM MEDIS RUMAH SAKIT SWASTA X
}

\author{
Iik Sartika \\ Program Studi Ilmu Kesehatan Masyarakat, Universitas Veteran Bangun Nusantara Sukoharjo \\ Email: iiksartika.8@gmail.com
}

\begin{abstract}
Abstrak
Rumah sakit adalah salah satu contoh organisasi padat karya dengan segala macam sumber daya manusia didalamnya. Rumah sakit juga merupakan institusi pelayanan kesehatan yang menjadi pusat pelayanan bagi masyarakat. Salah satu masalah yang tampak adalah sikap karyawan yang mengurangi kualitas pelayanan rumah sakit. Aktivitas Organizational Citizenship Behavior (OCB) di unit rekam medis Rumah Sakit Swasta X belum berjalan dengan baik. Ada empat karyawan yang memiliki tingkat OCB yang rendah dan dua karyawan memiliki tingkat OCB yang tinggi. Faktor penyebab ada tidaknya OCB di pelayanan rekam medis Rumah Sakit Swasta X adalah role clarity, leadership, motivational drives, organizational commitment, organizational justice, dan individual traits. Rekomendasi yang dapat diaplikasikan untuk meningkatkan OCB di unit rekam medis Rumah Sakit Swasta $\mathrm{X}$ adalah sebagai berikut: 1) Memperjelas tugas pokok dan fungsi karyawan (Role Clarity), 2) Role model dari pemimpin (Leadership), 3) Memasang kata motivasi (Motivational Drives), 4) Meningkatkan komitmen organisasi dengan apresiasi dari organisasi (Organizational Commitment), 5) Perlakuan yang sama terhadap karyawan (Organizational Justice), 6) Pengembangan self confidance, team building, dan leadership untuk karyawan (Individual Traits). Kata kunci : OCB, rekam medis, SDM
\end{abstract}

\begin{abstract}
The hospital is one example of a labor intensive organization with all sorts of human resources therein. The hospital is also a health care institution that is the center of service for the community. One of the problems that seemed is the attitude of employees who reduce the quality of hospital services. Organizational Citizenship Behavior (OCB) 's activity in the medical record unit of private hospital $\mathrm{X}$ has not been going well. There are four employees who have low OCB levels and two employees have a high OCB level. The causal factor of OCB in private hospital X medical record service is role clarity, leadership, motivational drives, organizational commitment, organizational justice, and traits individual. The recommendations that can be applied to improve OCB in the medical record unit of private hospital $\mathrm{X}$ are as follows: 1) clarify the basic task and function of the employee (Role Clarity), 2) Role model of the leader (Leadership), 3) put the word motivation ( Motivational Drives), 4) Increase organizational commitment with appreciation from the Organization (Organizational Commitment), 5) Equal treatment of employees (Organizational Justice), 6) Development of self confidance, team building, and leadership Employees (Individual Traits).
\end{abstract}

Keywords: OCB, medical record, human resources 
Volume 02, No 01, Tahun 2019

ISSN: 2621-6612

Email: d3perinfokesunivet@gmail.com

Halaman: $37-46$

\section{PENDAHULUAN}

Manajemen sumber daya manusia adalah ilmu dan seni untuk mengatur dan mengelola sumber daya manusia didalamnya untuk mencapai tujuan organisasi. Aspek sumber daya manusia merupakan bagian yang tidak terpisahkan dari manajemen organisasi, yaitu salah satu faktor penentu keberhasilan organisasi dalam mencapai tujuan organisasi. Sumber daya manusia di sebuah organisasi tidak hanya diposisikan sebagai aset produksi tetapi lebih sebagai aset yang harus dikelola dan dikembangkan. Salah satu organisasi padat karya adalah rumah sakit dengan segala macam sumber daya manusia didalamnya. Rumah sakit adalah suatu institusi pelayanan kesehatan yang menjadi pusat pelayanan bagi masyarakat. Salah satu masalah yang tampak adalah sikap karyawan yang kurang menguntungkan bagi kemajuan rumah sakit.

Rumah Sakit Swasta X adalah salah satu rumah sakit swasta yang ada di Kabupaten Tuban. Rumah sakit sebagai tempat pelayanan kesehatan berkewajiban memberikan pelayanan yang maksimal pada pasien. Pelayanan pada pasien di rumah sakit sangat dipengaruhi oleh sumber daya manusianya. Fenomena permasalahan terkait sumber daya manusia juga terjadi di Rumah Sakit Swasta X tepatnya di bagian pelayanan rekam medis. Berdasarkan survey kepuasan pasien yang dilaksanakan rumah sakit,

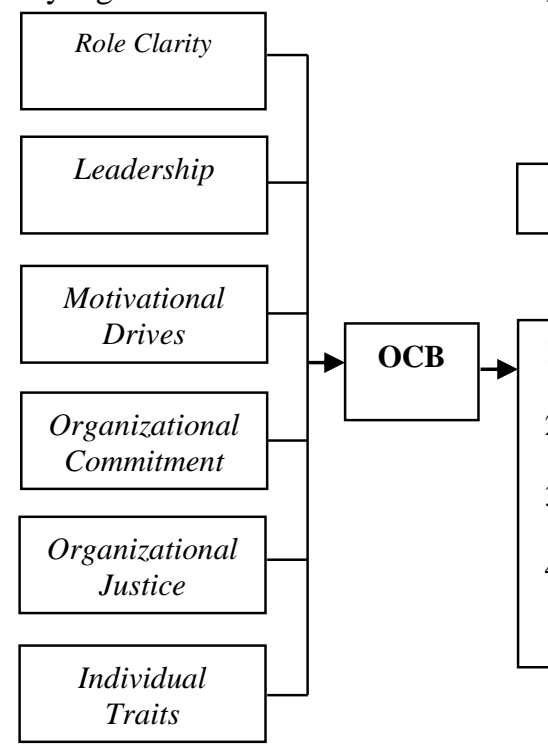

adanya ketidakpuasan pasien sebesar $45 \%$ terhadap pelayanan petugas rekam medis di Rumah Sakit Swasta X. Ketidakpuasan dikarenakan pelayanan di unit rekam medis yang lama dan tidak jelas. Permasalahan tersebut dapat disebabkan oleh kurangnya kerjasama antar karyawan yang ada di pelayanan rekam medis. Hal ini merupakan ciri kurangnya aktivitas Organizational Citizenship Behavior (OCB) di pelayanan rekam medis Rumah Sakit Swasta X.

Rumusan masalah dalam penelitian ini adalah bagaimana aktivitas OCB karyawan dan apa saja faktor penyebab kurangnya Organizational Citizenship Behavior (OCB) karyawan di pelayanan rekam medis Rumah Sakit Swasta X ?

\section{Landasan Teori}

Organizational Citizenship

Behavior (OCB) merupakan perilaku individu yang ekstra, yang tidak secara langsung atau eksplisit dapat dikenali dalam suatu sistem kerja yang formal, dan yang secara agregat mampu meningkatkan efektivitas fungsi organisasi. Organisasi pada umumnya percaya bahwa untuk mencapai keunggulan harus mengusahakan kinerja individual yang setinggi-tingginya, karena pada dasarnya kinerja individual mempengaruhi kinerja tim atau kelompok kerja dan pada akhirnya mempengaruhi kinerja organisasi secara keseluruhan. Secara konsep dapat digambarkan sebagai berikut:

Gambar 1. Conceptual Framework of Organizational Citizenship Behavior Sumber : (Chahal \& Mehta, 2010)

1. Kejelasan Peran (Role Clarity) 
Kejelasan Peran berfokus pada tugas dan tanggung jawab seorang individu yang diharapkan untuk melakukan pekerjaan dalam suatu organisasi. Hal ini berhubungan positif dengan OCB secara umum dan dengan altruisme, hati nurani, kepatuhan organisasi, inisiatif individu dan civic virtue pada khususnya. Berdasarkan literatur, empat dimensi kejelasan peran adalah efikasi peran, tanggungjawab peran, kinerja peran, dan konflik peran. Efikasi peran, tanggungjawab peran, dan kinerja peran diidentifikasi berhubungan positif dengan OCB (Bray \& Lawrence R, 2002), sementara konflik peran berhubungan negatif dengan OCB (Nagai et al., 2008).

Keberhasilan peran adalah persiapan untuk membedakan antara peran interdependen spesifik menguntungkan dan tidak menguntungkan dalam peran keseluruhan seorang individu yang diharapkan untuk melakukan suatu pekerjaan dalam suatu organisasi (Bray \& Lawrence R, 2002). Tanggung jawab peran adalah kewajiban karyawan yang merupakan upaya terbaik karyawan untuk mencapai tujuan organisasi sehingga kinerja karyawan menjadi lebih baik dan dapat menyebabkan kepuasan kerja (Nagai et al., 2008).

Kejelasan peran menjadi anteseden OCB yang memberikan kontribusi untuk efektivitas dalam organisasi yang beroperasi di berbagai sektor. Demikian juga dalam tujuan yang jelas sektor kesehatan dari dokter, perawat, staf paramedis bersama dengan masing-masing tugas dan tanggung jawab yang diberikan akan membuat kinerja karyawan medis yang lebih baik 'yang kemudian akan menyebabkan kepuasan pasien.

\section{Kepemimpinan (Leadership)}

Kepemimpinan adalah pengaruh antarpribadi yang dilakukan melalui proses komunikasi ke arah pencapaian tujuan yang ditentukan. Kepemimpinan memainkan peran penting di semua sektor. Misalnya, kepala berbagai departemen khusus dalam organisasi pelayanan kesehatan dapat memainkan peran penting dalam meningkatkan semangat tim, moral dan kekompakan karyawan medis, sehingga dapat meningkatkan kepuasan pasien dan efektivitas organisasi.

$$
\text { Gaya kepemimpinan yang }
$$
ditunjukkan oleh pemimpin organisasi terbukti dapat meningkatkan OCB karyawan. Selain itu kualitas hubungan pimpinan dan karyawan yang biasanya disebut leader member exchange dapat menyebabkan munculnya kepuasan kerja maupun komitmen organisasi yang merupakan anteseden OCB (Jahangir et al., 2004).

3. Motivational Drives

Motivational Drives adalah kekuatan yang dapat merangsang karyawan untuk bekerja atau untuk bekerja lebih dan lebih baik. Mereka memiliki pengaruh kuat pada kesediaan karyawan untuk terlibat dalam OCB. Motivational Drives yang positif berkaitan dengan OCB secara umum dan dengan altruisme, kelelahan, kesadaran, kepatuhan organisasi , inisiatif individu dan civic virtue pada khususnya. Misalnya, di sektor kesehatan manajemen rumah sakit dapat mendorong karyawan medis (dokter, perawat, paramedis staf) untuk berpartisipasi aktif dalam pertemuan unit kerja yang akan membantu dalam integrasi anggota tim sehingga menyebabkan peningkatan efektifitas dan efisiensi kelompok. Karyawan yang hadir dan berpartisipasi aktif dalam pertemuan dapat membantu dalam penyebaran informasi dalam suatu organisasi, sehingga meningkatkan respon secara langsung dan kepuasan pasien secara tidak langsung (Jahangir et al., 2004).

4. Komitmen Organisasi (Organizational Commitment) Komitmen organisasi dapat didefinisikan sebagai sejauh mana seorang individu menerima dan menginternalisasi tujuan dan nilai-nilai organisasi dan memandang peran organisasi dalam hal kontribusinya terhadap tujuan dan nilai-nilai tersebut. Komitmen organisasi berhubungan negatif dengan turnover, absensi dan perilaku tidak produktif. Komitmen organisasi berhubungan positif dengan kepuasan kerja, motivasi dan OCB. Hubungan positif antara komitmen organisasi, OCB dan efektivitas organisasi akan lebih tinggi untuk rumah sakit swasta dibandingkan dengan rumah sakit umum (Lok Peter et al., 2007).

\section{Keadilan Organisasi (Organizational justice)}

Keadilan organisasi mengacu pada persepsi seseorang tentang keadilan dalam organisasi. Hal ini secara signifikan 
berhubungan dengan OCB pada umumnya, dan dengan altruisme, civic virtue, kesadaran dan sportivitas khususnya. Pada sektor kesehatan, keadilan organisasi dapat meningkatkan kesamaan kelompok, rasa belongingness antara semua karyawan departemen medis khusus yang pada gilirannya membantu untuk menarik dan mempertahankan karyawan medis yang lebih baik termasuk dokter, perawat, staf dan paramedis (Meyer et al., 1997).

6. Karakterisktik Individu

Karakteristik individu adalah integrasi total fisik, intelektual, emosional dan sosial dan karakteristik yang membentuk individu dan yang dinyatakan dalam bentuk perilaku, pengalaman, sopan santun, sikap, nilai, keyakinan, ambisi, aspirasi, kepentingan, kebiasaan dan temperamen (Ashton \& Lee, 2007). Karakteristik individu yang berhubungan dengan tempat kerja yaitu efektivitas positif negatif efektivitas, kesadaran dan keramahan dan sifat-sifat pribadi yaitu extraversion, introversion atau keterbukaan untuk mengubah secara positif berhubungan dengan OCB secara umum dan dengan altruisme, sportif, civic virtue, kepatuhan organisasi khususnya. Karakteristik individu yang berhubungan dengan tempat kerja serta sifat pribadi dapat mempengaruhi karyawan medis (perawat, tenaga paramedis) untuk mengkoordinasikan kebutuhan karyawan dengan kebutuhan organisasi yang lebih fleksibel yang pada gilirannya akan meningkatkan kepuasan karyawan dan meningkatkan kepuasan pasien (Jahangir et al., 2004).

\section{METODE}

Penelitian menggunakan metode deskriptif dan apabila dilihat dari waktu penelitiannya termasuk studi cross sectional karena pengumpulan data dilakukan pada satu waktu tertentu untuk menggambarkan kegiatan dan kondisi pada waktu tersebut (Kuntoro, 2008). Unit analisis yang diteliti adalah unit rekam medis di Rumah Sakit Swasta X. Instrumen penelitian yang digunakan berupa lembar observasi dan kuesioner. Pengumpulan data dilakukan dengan mengamati proses pelayanan di rekam medis yang dilaksanakan oleh petugas rekam medis, dan wawancara dengan petugas.
Analisis data penelitian menggunakan analisis deskriptif yaitu menganalisis proses pelayanan yang dilakukan oleh petugas rekam medis, kemudian mengidentifikasi faktor penyebab kurangnya kerjasama antar petugas. Hasil pengamatan tersebut akan dibuat isu strategis kemudian akan menghasilkan rekomendasi dalam upaya peningkatan tingkat kepuasan pasien terhadap pelayanan unit rekam medis di Rumah Sakit Swasta X.

\section{HASIL DAN PEMBAHASAN \\ Aktivitas Pelayanan Unit Rekam Medis} Pelayanan rekam medis di Rumah

Sakit Swasta X, hanya terdiri dari satu rekam medis yang dijaga oleh dua karyawan secara bergantian. Pelayanan untuk pasien umum lebih sederhana karena rekam medis hanya menyiapkan berkas. Sementara untuk pasien asuransi membutuhkan waktu yang lebih lama dan proses yang rumit. Saat pasien asuransi datang dan hendak dirawat, bagian informasi atau rekam medis akan konfirmasi pada pihak asuransi via telepon. Bagian informasi juga akan menyalurkan informasi pada bagian rekam medis untuk mengirimkan laporan medis awal dari dokter. Bagian pelayanan rekam medis berkewajiban untuk mengirimkan berkas pasien meliputi laporan medis awal pasien via fax atau email, kemudian bagian rekam medis juga yang bertugas konfirmasi ke pihak asuransi via telepon setelah mengirimkan berkas pasien tersebut. Apabila ada berkas yang kurang lengkap, bagian rekam medis jugalah yang konfirmasi pada dokter atau perawat yang mengetahui terkait diagnosis pasien. Saat pasien asuransi yang dirawat inap akan pulang, bagian rekam medis akan mengirimkan semua berkas pasien ke pihak asuransi, untuk mengetahui apakah biaya pasien terbayarkan oleh asuransi atau tidak. Proses ini yang membutuhkan waktu lama sehingga pasien terkadang menunggu lama. Penyebabnya adalah terdapat beberapa karyawan yang kurang tanggap terhadap permasalahan tersebut dan malah menyerahkan pada karyawan lainnya tanpa membantu. Karyawan juga kurang kerjasama sehingga sering terjadi kesalahpahaman.

Pelayanan di rekam medis Rumah Sakit Swasta X terdiri dari tiga shift kerja meliputi shift pagi, sore dan malam. Sumber daya manusia yang ada didalamnya meliputi 
satu kepala bagian pelayanan rekam medis, satu karyawan non shift, dan 4 karyawan yang bekerja dalam shift. Dalam satu shift terdiri dari dua karyawan. Dua karyawan perempuan dan dua laki-laki. Pelayanan yang ada di rekam medis hanya ada satu loket melayani transaksi pembayaran pasien rawat jalan dan rawat inap. Pasien terdiri dari pasien umum dan pasien asuransi. Kondisi layanan kesehatan seperti ini merupakan persoalan yang mencerminkan indikasi adanya gejala Organizational Citizenship Behavior (OCB) yang rendah di lingkungan karyawan bagian pelayanan rekam medis. Organizational Citizenship Behavior (OCB) adalah kontribusi individu dalam melebihi tuntutan pekerjaan di tempat kerja meliputi perilaku suka menolong, peduli, patuh pada aturan dan rela melakukan tugas extra role di tempat kerja.

Masalah yang terjadi di bagian pelayanan rekam medis adalah adanya ketidakpuasan pasien terhadap pelayanan rekam medis yang dinilai rumit dan lama sebesar $30 \%$. Salah satu penyebabnya adalah kurangnya kerjasama dan perilaku saling membantu antar karyawan di pelayanan rekam medis Rumah Sakit Swasta X. Perilaku ini adalah salah satu indikasi kurangnya OCB di pelayanan rekam medis khususnya pada perilaku altruism.

\section{Aktivitas OCB}

Berdasarkan hasil observasi dan wawancara terkait aktivitas OCB dengan karyawan yang ada di pelayanan rekam medis Rumah Sakit Swasta X, didapatkan hasil bahwa dari 6 karyawan yang berada di pelayanan rekam medis terdapat 4 karyawan yang memiliki OCB rendah, dan 2 karyawan memiliki OCB yang tinggi. Karyawan yang memiliki OCB rendah adalah karyawan senior dimana dua diantaranya adalah karyawan laki-laki. Karyawan laki-laki cenderung kurang peduli terhadap masalah karyawan lain dan tidak membantu. Hal ini menunjukkan sikap altruism karyawan lakilaki yang masih rendah. Hal ini sesuai dengan penelitian Konrad, et al. (dalam Novliadi, 2007) mengemukakan bahwa perilaku kerja seperti menolong orang lain, bersahabat dan bekerjasama dengan orang lain lebih nampak dilakukan oleh wanita daripada pria. Beberapa penelitian juga menunjukkan bahwa wanita cenderung lebih mengutamakan pembentukan relasi (relational identities) daripada pria. Penjelasan tersebut menunjukkan bahwa ada perbedaan yang cukup mencolok antara lakilaki dan perempuan dalam perilaku menolong dan interaksi sosial ditempat kerja.

Karyawan senior lebih sering meninggalkan tempat kerja untuk keperluan pribadi dan menyerahkan tanggungjawabnya pada karyawan junior. Hal ini menyebabkan pekerjaan menjadi menumpuk dan pelayanan terhadap pasien semakin lama. Hal ini bertolak belakang dengan penelitian yang dilakukan oleh Jahangir (2004) bahwa semakin lama karyawan bekerja di organisasi maka tingkat OCB pada karyawan juga semakin tinggi, hal ini karena mereka memiliki loyalitas yang tinggi pada organisasi. Berdasarkan hasil wawancara diperoleh alasan bahwa karyawan senior kadang merasa bosan dengan rutinitas pekerjaan yang dikerjakan. Menurut penelitian Bacrach et al, (2006) karakteristik pekerjaan yang melibatkan diri sendiri secara aktif cenderung menjadi anteseden OCB dibandingkan karakteristik pekerjaan yang rutin dan kurang mandiri karena pekerjaan yang rutin menyebabkan karyawan merasa bosan dan tidak bisa mengembangkan kreativitasnya sehingga enggan untuk berinisiatif secara spontan untuk melakukan sesuatu yang berguna bagi organisasi.

Dalam pelayanan pada pasien asuransi swasta, karyawan dengan OCB rendah cenderung melimpahkan tugas pada karyawan juniornya dan tidak membantu apabila ada permasalahan. Perilaku karyawan senior tidak menunjukkan perilaku altruism. Karyawan junior yang dari segi usia juga lebih muda justru yang memiliki OCB lebih tinggi dengan sukarela melaksanakan tugas dengan sebaik-baiknya. Hal ini bertolak belakang dengan penelitian Jahangir (2004) bahwasanya usia akan sangat berpengaruh, dimana karyawan yang lebih muda memiliki OCB lebih rendah dibandingkan karyawan yang lebih tua, akan berbeda didalam orientasi mereka terhadap diri mereka sendiri, orang lain, dan terhadap pekerjaan, perbedaan yang semacam ini akan berujung pada motif-motif untuk melakukan OCB.

Karyawan junior yang memiliki OCB tinggi memperlihatkan kinerja yang lebih baik, dengan dapat menyelesaikan masalah yang sering ditimbulkan oleh 
karyawan senior. Hal ini sesuai dengan penelitian Bachrach et al. (2006) menyebutkan bahwa perolehan kinerja tinggi lebih sering dihubungkan dengan perilaku menolong pekerja ketika tugas-tugas sebuah unit kerja saling terkait satu sama lain, dan hal itu semakin meningkatkan kinerja organisasi. Hubungan OCB dan performance berdasarkan hasil penelitiannya, didapatkan hasil bahwa OCB memiliki hubungan yang positif disetiap dimensinya terhadap variabel kerja. Sehingga karyawan yang menampilkan OCB tinggi akan menunjukkan untuk kerja yang tinggi pula, begitu juga sebaliknya bila OCB karyawan rendah maka kerjanya juga rendah (Nielsen, et al. 2009).

Karyawan yang memilki OCB rendah juga kurang toleransi terhadap karyawan lainnya, misalnya saat pembagian shift kerja, karyawan senior membagi kurang adil sehingga karyawan junior yang terkena imbasnya. Hal ini tidak sesuai dengan salah satu dimensi OCB yaitu sportsmanship. Fakta yang terjadi di pelayanan rekam medis Rumah Sakit Swasta X, terkait pergantian shift kerja pada karyawan. Salah seorang karyawan yang seharusnya shift malam tibatiba tidak bisa memenuhi tanggung jawabnya untuk bekerja dikarenakan adanya suatu urusan yang harus dia selesaikan. Kemudian dia meminta tolong kepada temannya yang bekerja shiftnya sore untuk meneruskan dan menggantikannya. Fakta tersebut dapat dijadikan indikasi adanya OCB pada karyawan (sportsmanship).

Penelitian Bienstock, et al. (2003) mengenai OCB dan pelayanan, menyimpulkan bahwa semakin tinggi tingkat OCB pada pekerja jasa maka semakin tinggi pula tingkat kepatuhan pekerja jasa pada aturan standart pelayanan. Dalam hal kualitas dan kuantitas kinerja kelompok, perilaku altruism dan sportsmanship dalam dimensi OCB memiliki efek yang signifikan terhadap kuantitas kerja. Dan perilaku altruism sendiri memiliki efek yang signifikan terhadap kualitas kinerja kelompok (Podsakoff, et al. 1997). Pekerja yang membantu pekerja lain dengan memberikan waktunya pada pekerja lain yang memiliki kesulitan dalam bekerja, membagi keahliannya dan mengambil langkah untuk mencegah terjadinya maslah dengan pekerja lain, membuat anggota pekerja lainnya lebih produktif, baik dalam kualitas maupun kuantitas, daripada pekerja yang tidak menunjukkan perilaku menolong. Menurut Organ (1995) terdapat bukti kuat yang mengemukakan bahwa budaya organisasi merupakan suatu kondisi awal yang memicu terjadinya OCB. Selain itu didalam iklim organisasi yang positif, karyawan merasa lebih ingin melakukan pekerjaannya melebihi apa yang telah disyaratkan dalam uraian pekerjaan, dan akan selalu mendukung tujuan organisasi, jika mereka diperlakukan oleh para atasan dengan sportif dan dengan penuh kesadaran serta percaya bahwa mereka diperlakukan secara adil oleh organisasi. Menurut Gunarsa (2008) pada umumnya tidak seorangpun dapat bekerja sendiri tanpa adanya seorang atau beberapa orang lain dalam hubungan kerja sama. Demikian pula dengan karyawan di rumah sakit juga membutuhkan kerja sama dengan karyawan lainnya. Komunikasi yang baik antar karyawan sangat diperlukan untuk mencapai efektifitas organisasi.

\section{Faktor Penyebab}

Berdasarkan hasil analisis aktivitas OCB di pelayanan rekam medis Rumah Sakit Swasta X, dapat dirumuskan beberapa faktor penyebab muncul atau tidaknya perilaku OCB pada karyawan di pelayanan rekam medis Rumah Sakit Swasta X adalah sebagai berikut:

\section{Role Clarity}

Karyawan dengan OCB rendah merasa kurang jelas terkait tugas pokok dan fungsi mereka di bagian pelayanan rekam medis. Tugas yang diberikan terkadang bukan merupakan tugasnya melainkan limpahan tugas dari bagian lain.

\section{Leadership}

Karyawan dengan OCB rendah merasa kurang adanya role model dari pemimpin yaitu kepala bagian rekam medis. Kepala bagian rekam medis jarang sekali membantu apabila ada masalah yang terjadi di rekam medis. Kepala bagian rekam medis juga jarang memberikan arahan dan motivasi pada karyawan lainnya.

\section{Motivational Drives}

Karyawan kurang mendapatkan motivasi dari manajemen rumah sakit. Motivasi yang kurang adalah terkait apresiasi dan rewads yang jarang diberikan oleh pihak manajemen.

\section{Organizational Commitment}

Karyawan yang merasa belum puas dengan apresiasi dari organisasi cenderung 
belum berkomitmen yang baik terhadap organisasi. Bahkan beberapa karyawan memiliki rencana untuk resign dan mencari pekerjaan lainnya. Komitmen karyawan terhadap organisasi akan meningkat apabila kepuasan karyawan juga meningkat.

\section{Organizational Justice}

Karyawan masih merasa belum diperlakukan secara adil oleh organisasi. Hal ini dikarenakan beban kerja yang mereka anggap terlalu besar sementara apresiasi yang diberikan organisasi dirasa sangat kurang.

\section{Individual Traits}

Karakteristik individu meliputi usia, lama bekerja, jenis kelamin, kepribadian karyawan (emosi,semangat kerja,motivasi kerja, kepedulian) dan persepsi terhadap organisasi.

\section{Rekomendasi}

Beberapa faktor penyebab terjadinya OCB di pelayanan rekam medis Rumah Sakit Swasta X dapat dijadikan bahan pertimbangan untuk meningkatkan OCB di pelayanan rekam medis Rumah Sakit Swasta $\mathrm{X}$. Adapun rekomendasi yang dapat diberikan untuk perbaikan aktivitas OCB di pelayanan rekam medis adalah sebagai berikut:

1. Memperjelas tugas pokok dan fungsi karyawan (Role Clarity)

Kejelasan peran setiap karyawan dapat ditingkatkan dengan rancangan tupoksi tiap karyawan dengan jelas. Tupoksi tersebut kemudian dapat ditempel di ruangan sehingga karyawan terpacu untuk selalu melaksanakan pekerjaan sesuai tanggungjawabnya. Kejelasan peran pada karyawan berhubungan positif dengan OCB. Semakin jelas tugas dan fungsi karyawan, maka semakin baik kinerja dari karyawan tersebut. Apabila kinerja karyawan maksimal maka pasien akan puas terhadap pelayanan yang diberikan (Bray \& Lawrence R, 2002).

Peran yang mewajibkan karyawan harus bekerjasama juga dapat dijelaskan dengan rinci, sehingga kinerja kelompok karyawan juga meningkat. Keterkaitan yang erat antara OCB dan kinerja kelompok. Adanya perilaku altruism memungkinkan sebuah kelompok secara kompak dan efektif untuk saling menutupi kelemahan masingmasing. Keterkaitan erat antara OCB dengan kinerja kelompok, terutama terjadi dengan tingginya hasil kerja kelompok secara kuantitas (Podsakoff, 1997).
2. Role model dari pemimpin (Leadership)

Karyawan dalam sebuah organisasi yang dipimpin dengan gaya kepemimpinan transformasional menunjukkan OCB secara alami. Gaya kepemimpinan transformasional lebih cocok digunakan di rumah sakit daripada gaya transaksional, karena kepala bagian memperlakukan karyawan sebagai mitra yang juga harus bertanggungjawab terhadap pekerjaan yang dijalankan sehingga meningkatkan ketrampilan karyawan dalam menjalankan tugasnya dan mengatasi masalah yang ditemukan dilapangan. Kepemimpinan transformasional adalah kemampuan seorang pemimpin dalam mengembangkan dan mengarahkan potensi dan kemampuan bawahan untuk mencapai bahkan melampaui tujuan organisasi. Menurut Jahangir, et al. (2004) gaya kepemimpinan yang ditunjukkan oleh pemimpin organisasi terbukti dapat meningkatkan OCB karyawan. Selain itu kualitas hubungan pimpinan dan karyawan yang biasanya disebut leader member exchange dapat menyebabkan munculnya kepuasan kerja maupun komitmen organisasi yang merupakan anteseden OCB.

3. Memasang kata motivasi (Motivational Drives)

Kata stimulus terkait OCB dapat ditempelkan di tempat pelayanan rekam medis yang dapat meningkatkan semangat kerja karyawan. Hal ini dapat memberikan dampak positif pada karyawan saat bekerja meskipun tidak memberikan dampak secara langsung pada perubahan sikap karyawan. Sesuai dengan penelitian yaitu pemasangan kata-kata stimulus seperti "bangun teamwork yang baik" kemudian "saling membantu antar rekan kerjamu" memberikan dampak positif pada perilaku karyawan yang secara tidak langsung menerapkan stimulus tersebut dalam lingkungan kerjanya.

4. Meningkatkan komitmen organisasi dengan apresiasi dari organisasi (Organizational Commitment)

Bentuk apresiasi dari organisasi pada karyawan meliputi gaji, reward, pujian akan prestasi, peningkatan jenjang karir dan ada juga non reward. Hal yang paling tampak mempengaruhi komitmen karyawan pada rumah sakit adalah terkait gaji. Hal ini sesuai dengan penelitian dari Garay (2006) yang mengemukakan karyawan yang merasa gaji yang diterima sesuai dengan harapannya akan 
semakin berkomitmen terhadap organisasi. Karyawan juga terdorong untuk berperilaku OCB. Hal ini memotivasi karyawan untuk bekerja extra role diluar kewajibannya. Perilaku inilah yang disebut dengan OCB atau dengan kata lain, OCB merupakan perilaku diluar deskripsi kerja yang telah ditentukan perusahaan, namun memiliki dampak yang baik bagi perusahaan. Karena OCB diluar deskripsi perusahaan, maka tidak ada pemberian rewads secara formal dari perusahaan.

5. Perlakuan yang sama terhadap karyawan (Organizational Justice)

Selama ini, penilaian kinerja dilakukan berdasarkan tugas pokok yang dilakukan oleh pekerja saja. Penambahan variabel OCB sebagai item penilaian kinerja membuat karyawan akan termotivasi untuk melakukan kegiatan extra-role, mengingat bahwa perilaku extra-role tidak bisa lepas dari peran utama yang dikerjakan oleh seorang pekerja. Namun, hal ini juga harus diimbangi dengan adanya sistem reward dan juga punishment.

Perlakuan yang sama oleh organisasi terhadap karyawan akan meningkatkan persepsi baik karyawan terhadap organisasi. Persepsi terkait organizational justice berhubungan positif dengan OCB khususnya dimensi altruism. Semakin positif persepsi karyawan maka semakin tinggi tingkat OCB pada karyawan (Jahangir et al., 2004).

6. Pengembangan self confidance, team building, dan leadership untuk karyawan (Individual Traits)

Kecerdasan emosi dan soft skill dapat ditingkatkan melalui pelatihan pengembangan diri diantaranya pengembangan self confidance, team building dan leadership. Pengembangan Self confidance, bertujuan tidak hanya untuk meningkatkan kepercayaan diri tetapi juga menyentuh kecerdasan emosional seseorang dengan membangkitkan kesadaran diri dan kendali dorongan, ketekunan, semangat dan motivasi diri serta empati dan kecakapan sosial. Sedangkan Pengembangan Team building, meningkatkan rasa saling ketergantungan, kerjasama, pentingnya komunikasi dan membangun suatu tim yang kompak adalah tujuan dari pelatihan ini dan merupakan rancangan sosiabilitas untuk meningkatkan kepekaan saraf yang menghubungkan antara otak individu yang satu dengan yang lain. Pengembangan Leadership, yang dapat mengasah jiwa kepemimpinan pada diri karyawan. Permasalahan-permasalahan yang ada perlu dihadapi oleh peserta dengan pengambilan keputusan yang berkualitas. Hal ini sesuai dengan penelitian dari Goleman (2007) yang menyatakan adanya hubungan positif antara kecerdasan emosi dengan OCB.

Perilaku OCB cenderung melihat seseoraang karyawan sebagai makhluk sosial menjadi anggota organisasi, dibandingkan sebagai makhluk individual yang mementingkan diri sendiri. Sebagai makhluk sosial manusia mempunyai kemampuan untuk memiliki empati kepada orang lain dan lingkungannya dan menyelaraskan nilai-nilai yang dimiliki lingkungannya untuk melakukan segala sesuatu yang baik manusia tidak selalu digerakkan oleh hal-hal yang menguntungkan dirinya, misalnya seorang mau membantu orang lain jika ada imbalan tertentu. Jika karyawan dalam organisasi memiliki OCB, maka usaha untuk mengendalikan karyawan menurun, karena karyawan dapat mengendalikan perilakunya sendiri atau mampu memilih perilaku terbaik untuk kepentingan organisasinya.

\section{Organizational Commitment}

Karyawan yang merasa belum puas dengan apresiasi dari organisasi cenderung belum berkomitmen yang baik terhadap organisasi. Bahkan beberapa karyawan memiliki rencana untuk resign dan mencari pekerjaan lainnya. Komitmen karyawan terhadap organisasi akan meningkat apabila kepuasan karyawan juga meningkat.

\section{Organizational Justice}

Karyawan masih merasa belum diperlakukan secara adil oleh organisasi. Hal ini dikarenakan beban kerja yang mereka anggap terlalu besar sementara apresiasi yang diberikan organisasi dirasa sangat kurang.

\section{Individual Traits}

Karakteristik individu meliputi usia, lama bekerja, jenis kelamin, kepribadian karyawan (emosi, semangat kerja, motivasi kerja, kepedulian) dan persepsi terhadap organisasi.

\section{SIMPULAN}

Berdasarkan penelitian ini diperoleh bahwa:

1. Aktivitas Organizational Citizenship Behavior (OCB) di pelayanan rekam 
medis Rumah Sakit Swasta X belum berjalan dengan baik.

2. Ada tiga karyawan yang memiliki tingkat OCB yang rendah dan dua karyawan memiliki tingkat OCB yang tinggi.

3. Faktor penyebab ada tidaknya OCB di pelayanan rekam medis Rumah Sakit Swasta $\mathrm{X}$ adalah role clarity, leadership, motivational drives, organizational commitment, organizational justice, dan individual traits.

4. Rekomendasi yang dapat diaplikasikan untuk meningkatkan OCB di pelayanan rekam medis Rumah Sakit Swasta X adalah sebagai berikut: 1) Memperjelas tugas pokok dan fungsi karyawan (Role Clarity), 2) Role model dari pemimpin (Leadership), 3) Memasang kata motivasi (Motivational Drives), 4) Meningkatkan komitmen organisasi dengan apresiasi dari organisasi (Organizational Commitment), 5) Perlakuan yang sama terhadap karyawan (Organizational Justice), 6) Pengembangan self confidance, team building, dan leadership untuk karyawan (Individual Traits).

\section{DAFTAR PUSTAKA}

Ashton, M.C. \& Lee, K., 2007. Empirical, Theorical and Practical Advantage of the HEXACO Model of Personality Review. II(2), pp.150-66.

Bachrach, Daniell G., Powell, Benjamin C., \& Bendoly, E. 2006. Organizational Citizenship Behavior and Performance Evaluations: Exploring The Impact of Task Interdependence. Journal of Applied Psychology.

Bienstock, Carol C., DeMoranville, Carol W., \& Smith, Rachel, K. (2003). Organizational Citizenship Behavior and Service Quality. Journal of Services Marketing.

Bray, S.R. \& Lawrence R, B., 2002. Role Efficacy, Role Clarity and Role Performance. Small Research Group, II(33), pp.233-53.

Chahal, H. \& Mehta, S., 2010. Antecedents and Consequences of Organizational Citizenship Behavior (OCB). Journal of Services Research, $\mathrm{X}$.

Gunarsa, S.D. 2008. Psikologi Perawatan. Jakarta: PT BPK Gunung Mulia
Jahangir, N., Akbar, M.M. \& Haq, M., 2004. Organizational Citizenship Behavior: Its Nature and Antecedents. Journal of BRAC University, I(2), pp.75-85.

Lok Peter, P.Z., Wang, B.W. \& Crawford, H., 2007. Antecedents of Job Satisfaction and Organizational Commitment and Mediating Role of Organizational Subculture. International Graduate School of Business, pp.1-42.

Lovell, S. E., Kahn, A. S., Anton, J., Davidson, A., Dowling, E., Post, D., dan Mason, C. 1999. "Does Gender Affect The Link Between Organizational Citizenship Behavior and Preference Evaluation?". Sex Roles, Vol. 41.

Meyer, J.P., Organ, D.W. \& Graham, J.W., 1997. Individual Performance Attitudes and Behavior. Journal of International Review of Organizational Psychology, (12), pp.175-228.

Nagai, H. et al., 2008. Expatriate Management in China. IABR and TLC Conference Proceedings, pp.1-11.

Nielsen, T.M., Hrivnak. G.A., \& Shaw, M. (2009). Organizational Citizenship Behavior and Performance : A Meta Analysis of Group level research

Novliadi, F. 2007. Organizational Citizenship Behavior Karyawan ditinjau dari Persepsi terhadap Kualitas interaksi atasan bawahan dan persepsi terhadap dukungan organizational. Laporan Penelitian, Medan: Universitas Sumatera Utara.

Organ D, W., 1988. OCB : The Good Soldier Syndrome. Lexington: Lexington Books.

Organ, Dennis. W., Podsakoff, Philip. M., \& MacKenzie, Scott B. 2006. Organizational Citizenship Behavior its nature, antecedents, and consequences. United states of America: Sage Publication, Inc.

Podsakoff, Philip M, Ahearne, M, MacKenzie., \& Scott B. 1997. Organizational Citizenship Behavior and the Quantity and Quality of work group performance, Journal of Applied Psychology.

Walz, S.M \& Niehoff, B.P. 2000. Organizational Citizenship Behavior: their Relationship to Organizational Effectiveness. Journal of Hospitaly and Tourism Research 
Jurnal Manajemen Informasi dan Administrasi Kesehatan (J-MIAK)

Volume 02, No 01, Tahun 2019

ISSN: 2621-6612

Email: d3perinfokesunivet@gmail.com

Halaman: $37-46$ 